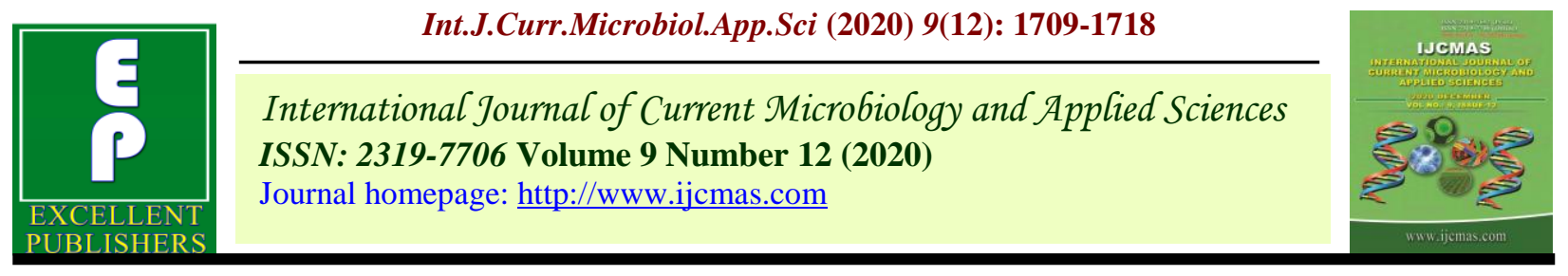

Original Research Article

https://doi.org/10.20546/ijcmas.2020.912.203

\title{
Bio-efficacy of Different Insecticides against Defoliator (Spodoptera litura) on Sunflower
}

\author{
A.S. Jadhav ${ }^{*}$, D.S. Mutkule, P.K. Waykule, B.A. Thakre and A.P. Dhormare \\ Oilseed Research Station, Latur- 413 512, Vasantrao Naik Marathwada Krishi Vidyapeeth, \\ Parbhani (M.S.), India \\ *Corresponding author
}

\section{A B S T R A C T}

\begin{tabular}{l} 
Ke y w or d s \\
$\begin{array}{l}\text { Spodoptera litura, } \\
\text { Bioefficacy, } \\
\text { Sunflower, } \\
\text { Insecticides }\end{array}$ \\
\hline Article Info \\
$\begin{array}{l}\text { Accepted: } \\
\text { 14 November } 2020 \\
\text { Available Online: } \\
10 \text { December } 2020\end{array}$ \\
\hline
\end{tabular}

An inspection was undertaken to study the bio-efficacy of different insecticides against defoliator (Spodoptera litura) on sunflower under field condition during Kharif, 2019 at research farm of Oilseed Research Station, Latur, Maharashtra, India. The observations on total number of Spodoptera litura were recorded on five randomly selected plants from each treatment at one day before and 3,7 and 14 days after first and second application of insecticides. The treatments of different insecticides viz., indoxacarb 0.019 per cent, emamectin benzoate 0.006 per cent, quinalphos 0.03 per cent, chlorantraniliprole 0.024 per cent, cypermethrin 0.03 per cent and profenophos 0.06 per cent were evaluated against Spodoptera litura revealed that emamectin benzoate 0.006 per cent was found most effective treatment in reducing the population of $S$. litura $(0.07$ and 0.00 larvae per five plants per plot at 3 days after first and second spray respectively), followed by chlorantraniliprole 0.024 per cent. Significantly higher seed yield $(2846 \mathrm{~kg} / \mathrm{ha})$ of sunflower was recorded in treatment emamectin benzoate 0.006 per cent, it was followed by treatment chlorantraniliprole 18.5 per cent $(2656 \mathrm{~kg} / \mathrm{ha})$. The highest ICBR $(1: 15.31)$ was recorded with treatment emamectin benzoate 0.006 per cent which was followed by cypermethrin 0.03 per cent $(1: 11.55)$.

\section{Introduction}

Sunflower (Helianthus annuus L.) belonging to family Compositae is one of the important oilseed crop and ranks third in area in the world. Sunflower is thermo and photoinsensitive crop. It is short durational and high yielding oilseed crop. Oil content in sunflower varies from 32 to 44 per cent. Also it contains 18 to 22 per cent of carbohydrates, 20 to 24 per cent of vitamins and 4 to 6 per cent of salts. Oil is also used for the manufacture of paints, cosmetics, soaps, etc. It is also used in the poultry, livestock rations and for the manufacture of baby foods. Karnataka state is the major producer of sunflower in the country. Maharashtra ranked third in area and production of sunflower.

In India, during 2017-18 sunflower was grown on an area of 0.33 million hectares with 0.23 million metric tonnes of production 
and 0.70 metric tonnes per hectare of productivity (Anonymous, 2019) ${ }^{[1]}$. The total production of sunflower in kharif, 2018-19 was estimated at 0.93 lakh tonnes $\left(4^{\text {th }}\right.$ advanced estimate, DACFW, GoI) and the production in Kharif, 2019-20 was estimated at 0.67 lakh tonnes ( $1^{\text {st }}$ advanced estimate, DACFW, GoI). In India, sunflower crop is damaged by different species of insect pests of which polyphagous pests like capitulum borer (Helicoverpa armigera Hubner), tobacco caterpillar (Spodoptera litura Fab.), Bihar hairy caterpillar (Spilosoma oblique Walker), green semilooper (Thysanoplusia orichalcea Fab.), cabbage semilooper (Trichoplusia ni Hubner) and cutworm (Agrotis spp.) are considered of major economic importance (Basappa, 1998) ${ }^{[3]}$.

If the defoliators (Spodoptera litura) attack is before flower initiation, it would affect food partitioning between stem, leaves and roots and if it is later it would affect growth of both vegetative parts and inflorescence. Bihar hairy caterpillar is highly polyphagous and occurs all over India and often reported to cause colossal damage to sunflower (Rohilla et al., 1981) ${ }^{[12]}$. Tobacco caterpillar may also assume injurious levels similar to Bihar hairy caterpillar. Though, different insecticides has been used against sunflower defoliators, according to several reports many of these label claimed insecticides could not gave effective results. Hence, some of the insecticides should have to be re-examined against insect-pests of sunflower.

\section{Materials and Methods}

The field experiment with sunflower crop using variety 'LSFH-171' in Kharif, 2019 was conducted at Oilseeds Research Station, Latur under Vasantrao Naik Marathwada Krishi Vidyapeeth, Parbhani, M.S., India. The experiment was conducted in a randomized block design (RBD) with seven treatments including untreated control with three replications. Sunflower crop was sown on 01 August, 2019 in a gross plot of $4.8 \mathrm{~m} \mathrm{x} 4.2 \mathrm{~m}$ maintaining net plot of $4.2 \mathrm{~m} \times 3.9 \mathrm{~m}$. The row to row distance of $60 \mathrm{~cm}$ and plant to plant distance of $30 \mathrm{~cm}$ was maintained. The dose of fertilizer at the rate of $60 \mathrm{~kg} \mathrm{~N}, 30 \mathrm{~kg}$ $\mathrm{P}_{2} \mathrm{O}_{5}$ and $30 \mathrm{~kg} \mathrm{~K} 2 \mathrm{O}$ per hectare was given at the time of sowing. The crop was grown with all recommended package of practices recommended by V.N.M.K.V., Parbhani except insect-pests management. The first spray of particular insecticidal treatment was made on appearance of pest and successive spray was given at 15 days interval using manually operated knapsack sprayer. The observations on total number of Spodoptera litura were recorded on five randomly selected plants from each plot at one day before spray and 3, 7 and 14 days after first and second application of insecticides.

\section{Results and Discussion}

The bio-efficacy data recorded for Spodoptera litura during Kharif, 2019 on sunflower.

\section{Sunflower defoliator (Spodoptera litura)}

\section{First spray}

Data relating to the effect of different insecticides on population of sunflower defoliator (Spodoptera litura) after first spray are presented in Table 1 and depicted in Fig. 1. The results disclosed that all the insecticides were found significantly superior over untreated control in reducing population of sunflower defoliator (Spodoptera litura) at 3, 7 and 14 days after first application of insecticides.

At three day after first spray, treatment T2 i.e. emamectin benzoate 5 SG @ 0.006 per cent treated plot observed significantly lowest population of $S$. litura (0.07 larvae/five 
plants/plot) which was followed by treatment T4 i.e. chlorantraniliprole 18.5 SC @ 0.024 per cent (0.13 larvae/five plants/plot) and treatment T1 i.e. indoxacarb 14.5 SC @0.019 per cent (0.27 larvae/five plants/plot) and all these three treatments were found statistically at par with each other. The next effective treatment was treatment T5 i.e. cypermethrin 25 EC @ 0.03 per cent (0.40 larvae/five plants/plot) which was followed by treatment T6 i.e. profenophos 50 EC @ 0.06 per cent (0.53 larvae/five plants/plot). Both of these treatments were found statistically at par with each other. The highest $S$. litura population (1.27 larvae/five plants/plot) was recorded in treatment $\mathrm{T} 7$ i.e. untreated control. The rest of the treatment T3 i.e. quinalphos 25 EC @ 0.03 per cent (0.73 larvae/five plants/plot) was intermediate.

At seven days after first spray, significantly lowest population of $S$. litura was noted in treatment T2 i.e. emamectin benzoate 5 SG @ 0.006 per cent (0.13 larvae/five plants/plot) followed by treatment T4 i.e. chlorantraniliprole 18.5 SC @ 0.024 per cent (0.20 larvae/five plants/plot) which was again followed by treatment T1 i.e. indoxacarb 14.5 SC @ 0.019 per cent (0.33 larvae/five plants/plot) and all these three treatments were found statistically at par with each other. The next best treatment was treatment T5 i.e. cypermethrin 25 EC @ 0.03 per cent $(0.53$ larvae/five plants/plot). Treatment T3 i.e. quinalphos $25 \mathrm{EC} @ 0.03$ per cent $(0.80$ larvae/five plants/plot) and treatment T6 i.e. profenophos 50 EC @ 0.06 per cent $(0.87$ larvae/five plants/plot) were next effective treatments in reducing $S$. litura population. The highest $S$. litura population of 1.53 larvae/five plants/plot was recorded in treatment $\mathrm{T} 7$ i.e. untreated control.

At fourteen days after first spray, significantly lowest population of $S$. litura was observed in treatment T2 i.e. emamectin benzoate 5 SG @
0.006 per cent (0.20 larvae/five plants/plot) followed by treatment T4 i.e. chlorantraniliprole 18.5 SC @ 0.024 per cent (0.33 larvae/five plants/plot). Both of these treatments were found statistically at par with each other. The subsequent order of effectiveness was treatment T1 i.e. indoxacarb 14.5 SC @ 0.019 per cent (0.53 larvae/five plants/plot) and treatment T5 i.e. cypermethrin 25 EC @ 0.03 per cent $(0.67$ larvae/five plants/plot) and were found statistically at par with each other. The next best treatment in reducing the population of $S$. litura was treatment T6 i.e. profenophos 50 EC @ 0.06 per cent (0.93 larvae/five plants/plot) which found statistically at par with treatment T3 i.e. quinalphos 25 EC @ 0.03 per cent (1.00 larvae/five plants/plot). Treatment T7 i.e. untreated control recorded the highest of 1.67 larvae/five plants/plot.

Thus after first spray, overall the plots treated with emamectin benzoate 5 SG @ 0.006 per cent recorded significantly lowest population of $S$. litura on sunflower to the tune of 0.07 , 0.13 and 0.20 larvae/five plants/plot at 3, 7 and 14 days after spraying, respectively over rest of the insecticidal treatments.

\section{Second spray}

The results in concern with the effect of different insecticides on population of sunflower defoliator ( $S$. litura) after second spray are presented in Table 2 and depicted in Fig. 2.

The data disclosed that all the insecticides under inspection were significantly superior over untreated control in reducing the population of defoliator ( $S$. litura) on sunflower at 3, 7 and 14 days after second spray.

At three days after second spray, significantly lowest population of $S$. litura (0.00 larvae/five 
plants/plot) was recorded in the plots treated with treatment $\mathrm{T} 2$ i.e. emamectin benzoate 5 SG@ 0.006 per cent which was found at par with treatment T4 i.e. chlorantraniliprole 18.5 SC @ 0.024 per cent (0.07 larvae/five plants/plot) and treatment T1 i.e. indoxacarb 14.5 SC @ 0.019 per cent (0.27 larvae/five plants/plot). The next best treatment was treatment T5 i.e. cypermethrin 25 EC @ 0.03 per cent (0.33 larvae/five plants/plot). The next effective treatments were treatment T6 i.e. profenophos 50 EC @ 0.06 per cent $(0.47$ larvae/five plants/plot) and treatment T3 i.e. quinalphos 25 EC @ 0.03 per cent $(0.60$ larvae/five plants/plot) and both of these treatments were found statistically at par with each other in reducing $S$. litura population. The highest population of $S$. litura (1.13 larvae/five plants/plot) was recorded in treatment T7 i.e. untreated control.

At seven days after second spray more or less same trend was observed and the treatment T2 i.e. emamectin benzoate 5 SG @ 0.006 per cent observed significantly effective in minimizing $S$. litura population $(0.07$ larvae/five plants/plot) which was followed by treatment $\mathrm{T} 4$ i.e. chlorantraniliprole 18.5 SC @ 0.024 per cent (0.13 larvae/five plants/plot) and treatment T1 i.e. indoxacarb 14.5 SC @ 0.019 per cent (0.33 larvae/five plants/plot). All these three treatments were found statistically at par with each other. The next best treatment was treatment T5 i.e. cypermethrin 25 EC @ 0.03 per cent $(0.40$ larvae/five plants/plot). The subsequent order of effectiveness was treatment T6 i.e. profenophos 50 EC @ 0.06 per cent $(0.53$ larvae/five plants/plot), treatment T3 i.e. quinalphos $25 \mathrm{EC} @ 0.03$ per cent $(0.67$ larvae/five plants/plot) and both of these treatments were found statistically at par with each other. The highest $S$. litura population of 1.30 larvae/five plants/plot was recorded in treatment $\mathrm{T} 7$ i.e. untreated control.
At fourteen days after second spray, significantly lowest population of $S$. litura was observed in treatment T2 i.e. emamectin benzoate 5 SG @ 0.006 per cent $(0.13$ larvae/five plants/plot) and was found at par with treatment T4 i.e. chlorantraniliprole 18.5 SC @ 0.024 per cent (0.20 larvae/five plants/plot). The next best treatment was treatment T5 i.e. cypermethrin 25 EC @ 0.03 per cent ( 0.47 larvae/five plants/plot). The subsequent order of effectiveness was treatment T1 i.e. indoxacarb 14.5 SC @ 0.019 per cent (0.53 larvae/five plants/plot), treatment T6 i.e. profenophos 50 EC @ 0.06 per cent (0.67 larvae/five plants/plot) and treatment T3 i.e. quinalphos 25 EC @ 0.03 per cent (0.80 larvae/five plants/plot). All these three treatments were found statistically at par with each other. The highest S. litura population (1.53 larvae/five plants/plot) was recorded in treatment $\mathrm{T} 7$ i.e. untreated control.

Thus, overall it was observed that the insecticidal treatments suppressed the S. litura population for initial period only. The population increased slowly after seven days onwards of the spray. Also, among the insecticides tested emamectin benzoate 5\% SG @ 0.006 per cent was found most effective as it recorded significantly lowest population of $S$. litura on sunflower to the extent of $0.00,0.07$ and 0.13 larvae/five plants/plot at 3, 7 and 14 days after spraying, respectively over rest of the insecticides.

The above findings are in confirmity with those of Gadhiya et al., (2013) ${ }^{[4]}$ and Naveen Kumar et al., (2015) ${ }^{[6]}$ who found emamectin benzoate effective in management of $S$. litura on groundnut. While Tatagar et al., (2009) ${ }^{[15]}$ found that emamectin benzoate was most effective in management of S. litura on chilli. Sharma et al., (2017) ${ }^{[13]}$ found emamectin benzoate effective against $S$. litura on soybean. 
Table.1 Effect of different insecticides on the larval population of sunflower defoliator (S. litura) (First spray)

\begin{tabular}{|c|c|c|c|c|c|c|}
\hline \multirow{3}{*}{$\begin{array}{l}\text { Tr. } \\
\text { No. }\end{array}$} & \multirow[t]{3}{*}{ Treatment } & \multirow{3}{*}{$\begin{array}{c}\text { Concentration } \\
\text { used }(\%)\end{array}$} & \multicolumn{4}{|c|}{ Mean population of $S$. litura larvae/five plants/plot } \\
\hline & & & \multirow{2}{*}{$\begin{array}{l}1 \text { day before } \\
\text { Spraying }\end{array}$} & \multicolumn{3}{|c|}{ Days after spraying } \\
\hline & & & & 3 & 7 & 14 \\
\hline T1 & Indoxacarb $14.5 \% \mathrm{SC}$ & 0.019 & $\begin{array}{c}1.13 \\
(1.27)^{*}\end{array}$ & $\begin{array}{c}0.27 \\
(0.87)\end{array}$ & $\begin{array}{c}0.33 \\
(0.91)\end{array}$ & $\begin{array}{c}0.53 \\
(1.02)\end{array}$ \\
\hline $\mathbf{T} 2$ & $\begin{array}{l}\text { Emamectin benzoate } 5 \% \\
\text { SG }\end{array}$ & 0.006 & $\begin{array}{c}1.07 \\
(1.25)\end{array}$ & $\begin{array}{c}0.07 \\
(0.75)\end{array}$ & $\begin{array}{c}0.13 \\
(0.79)\end{array}$ & $\begin{array}{c}0.20 \\
(\mathbf{0 . 8 3})\end{array}$ \\
\hline T3 & Quinalphos 25\% EC & 0.03 & $\begin{array}{c}1.13 \\
(1.28)\end{array}$ & $\begin{array}{c}0.73 \\
(1.10)\end{array}$ & $\begin{array}{c}0.80 \\
(1.14)\end{array}$ & $\begin{array}{c}1.00 \\
(1.22)\end{array}$ \\
\hline $\mathbf{T 4}$ & $\begin{array}{l}\text { Chlorantraniliprole } 18.5 \% \\
\text { SC }\end{array}$ & 0.024 & $\begin{array}{c}0.93 \\
(1.20)\end{array}$ & $\begin{array}{c}0.13 \\
(0.79)\end{array}$ & $\begin{array}{c}0.20 \\
(0.84)\end{array}$ & $\begin{array}{c}0.33 \\
(0.91)\end{array}$ \\
\hline T5 & Cypermethrin $25 \%$ EC & 0.03 & $\begin{array}{c}1.27 \\
(1.32)\end{array}$ & $\begin{array}{c}0.40 \\
(0.95)\end{array}$ & $\begin{array}{c}0.53 \\
(1.02)\end{array}$ & $\begin{array}{c}0.67 \\
(1.08)\end{array}$ \\
\hline T6 & Profenophos $50 \%$ EC & 0.06 & $\begin{array}{c}1.07 \\
(1.25)\end{array}$ & $\begin{array}{c}0.53 \\
(1.02)\end{array}$ & $\begin{array}{c}0.87 \\
(1.17)\end{array}$ & $\begin{array}{c}0.93 \\
(1.20)\end{array}$ \\
\hline T7 & Untreated Control & - & $\begin{array}{l}1.00 \\
(1.21)\end{array}$ & $\begin{array}{c}1.27 \\
(1.33)\end{array}$ & $\begin{array}{c}1.53 \\
(1.43)\end{array}$ & $\begin{array}{c}1.67 \\
(1.47)\end{array}$ \\
\hline & S.E \pm & & 0.09 & 0.05 & 0.05 & 0.06 \\
\hline & C.D. at $5 \%$ & & NS & 0.15 & 0.16 & 0.17 \\
\hline & C.V. $(\%)$ & & 12.56 & 8.81 & 8.69 & 9.03 \\
\hline
\end{tabular}

*Figures in parentheses are square $\operatorname{root}(x+0.5)$ transformed values. NS: Non significant 
Table.2 Effect of different insecticides on the larval population of sunflower defoliator (S. litura) (Second spray)

\begin{tabular}{|c|c|c|c|c|c|c|}
\hline \multirow{3}{*}{$\begin{array}{l}\text { Tr. } \\
\text { No. }\end{array}$} & \multirow[t]{3}{*}{ Treatment } & \multirow{3}{*}{$\begin{array}{l}\text { Concentration } \\
\text { used }(\%)\end{array}$} & \multicolumn{4}{|c|}{ Mean population of $S$. litura larvae/five plants/plot } \\
\hline & & & \multirow{2}{*}{$\begin{array}{l}1 \text { day before } \\
\text { Spraying }\end{array}$} & \multicolumn{3}{|c|}{ Days after spraying } \\
\hline & & & & 3 & 7 & 14 \\
\hline T1 & Indoxacarb $14.5 \% \mathrm{SC}$ & 0.019 & $\begin{array}{c}1.07 \\
(1.24)^{*}\end{array}$ & $\begin{array}{c}0.27 \\
(0.87)\end{array}$ & $\begin{array}{c}0.33 \\
(0.91)\end{array}$ & $\begin{array}{c}0.53 \\
(1.02)\end{array}$ \\
\hline $\mathbf{T} 2$ & $\begin{array}{l}\text { Emamectin benzoate } 5 \% \\
\text { SG }\end{array}$ & 0.006 & $\begin{array}{c}1.07 \\
(1.25)\end{array}$ & $\begin{array}{c}0.00 \\
(0.71)\end{array}$ & $\begin{array}{c}0.07 \\
(0.75)\end{array}$ & $\begin{array}{c}0.13 \\
(0.79)\end{array}$ \\
\hline T3 & Quinalphos 25\% EC & 0.03 & $\begin{array}{c}1.20 \\
(1.30)\end{array}$ & $\begin{array}{c}0.60 \\
(1.04)\end{array}$ & $\begin{array}{c}0.67 \\
(1.08)\end{array}$ & $\begin{array}{c}0.80 \\
(1.14)\end{array}$ \\
\hline T4 & $\begin{array}{l}\text { Chlorantraniliprole } 18.5 \% \\
\text { SC }\end{array}$ & 0.024 & $\begin{array}{c}1.27 \\
(1.32)\end{array}$ & $\begin{array}{c}0.07 \\
(0.75)\end{array}$ & $\begin{array}{c}0.13 \\
(0.79)\end{array}$ & $\begin{array}{c}0.20 \\
(\mathbf{0 . 8 3})\end{array}$ \\
\hline T5 & Cypermethrin 25\% EC & 0.03 & $\begin{array}{c}1.00 \\
(1.22)\end{array}$ & $\begin{array}{c}0.33 \\
(0.91)\end{array}$ & $\begin{array}{c}0.40 \\
(0.94)\end{array}$ & $\begin{array}{r}0.47 \\
(0.98)\end{array}$ \\
\hline T6 & Profenophos $50 \%$ EC & 0.06 & $\begin{array}{c}0.93 \\
(1.19)\end{array}$ & $\begin{array}{c}0.47 \\
(0.98)\end{array}$ & $\begin{array}{c}0.53 \\
(1.02)\end{array}$ & $\begin{array}{c}0.67 \\
(1.08)\end{array}$ \\
\hline T7 & Untreated Control & - & $\begin{array}{c}1.00 \\
(1.22)\end{array}$ & $\begin{array}{c}1.13 \\
(1.28)\end{array}$ & $\begin{array}{c}1.30 \\
(1.35)\end{array}$ & $\begin{array}{r}1.53 \\
(1.43)\end{array}$ \\
\hline & S.E. \pm & & 0.09 & 0.05 & 0.06 & 0.05 \\
\hline & C.D. at $5 \%$ & & NS & 0.16 & 0.17 & 0.16 \\
\hline & C.V. (\%) & & 12.05 & 9.92 & 10.09 & 8.96 \\
\hline
\end{tabular}

*Figures in parentheses are square $\operatorname{root}(\mathrm{x}+0.5)$ transformed values. NS: Non significant 
Int.J.Curr.Microbiol.App.Sci (2020) 9(12): 1709-1718

Fig.1 Effect of different insecticides on the larval population of sunflower defoliator (S. litura) at first spray

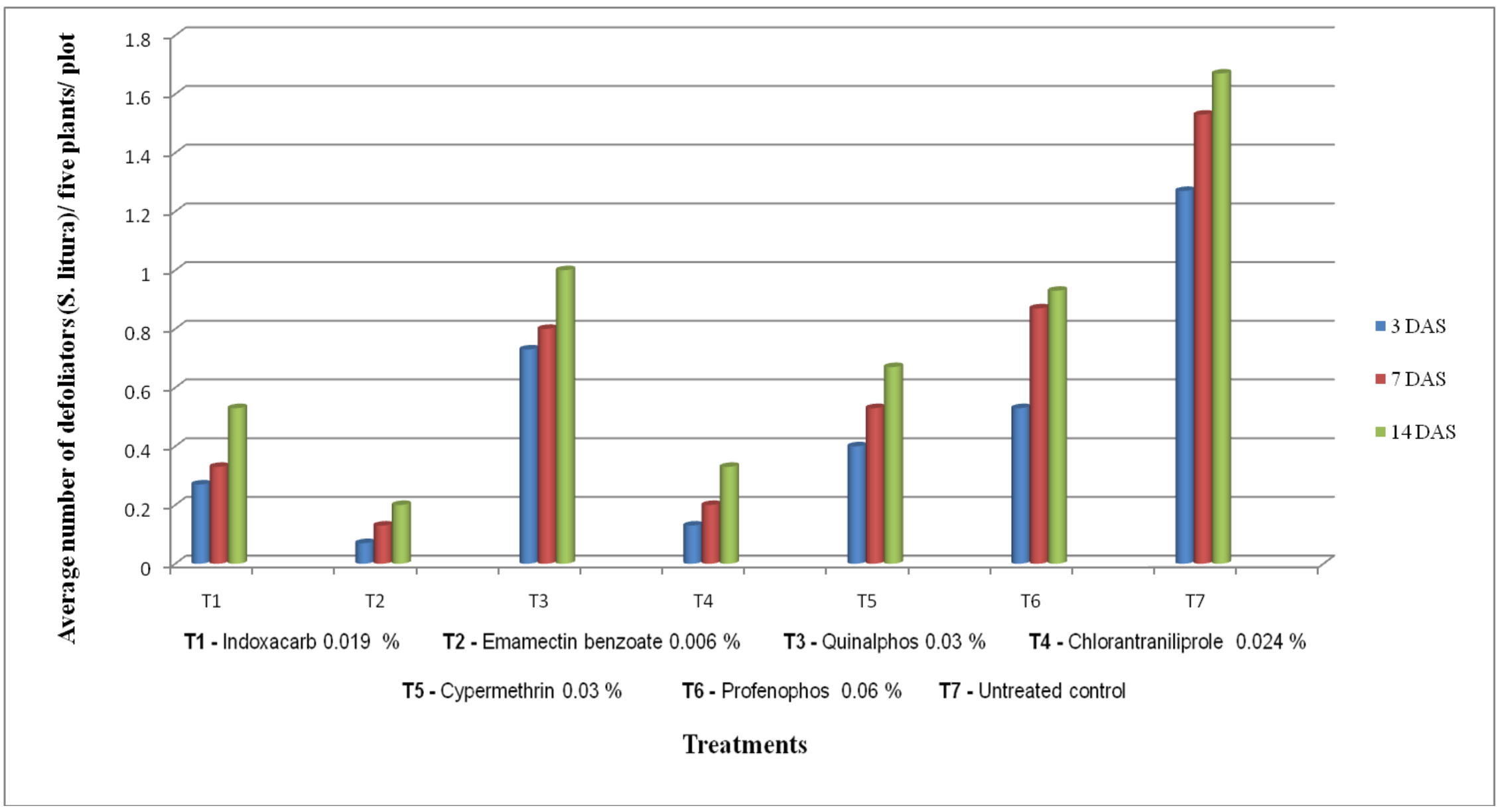


Int.J.Curr.Microbiol.App.Sci (2020) 9(12): 1709-1718

Fig.2 Effect of different insecticides on the larval population of sunflower defoliator (S. litura) at second spray

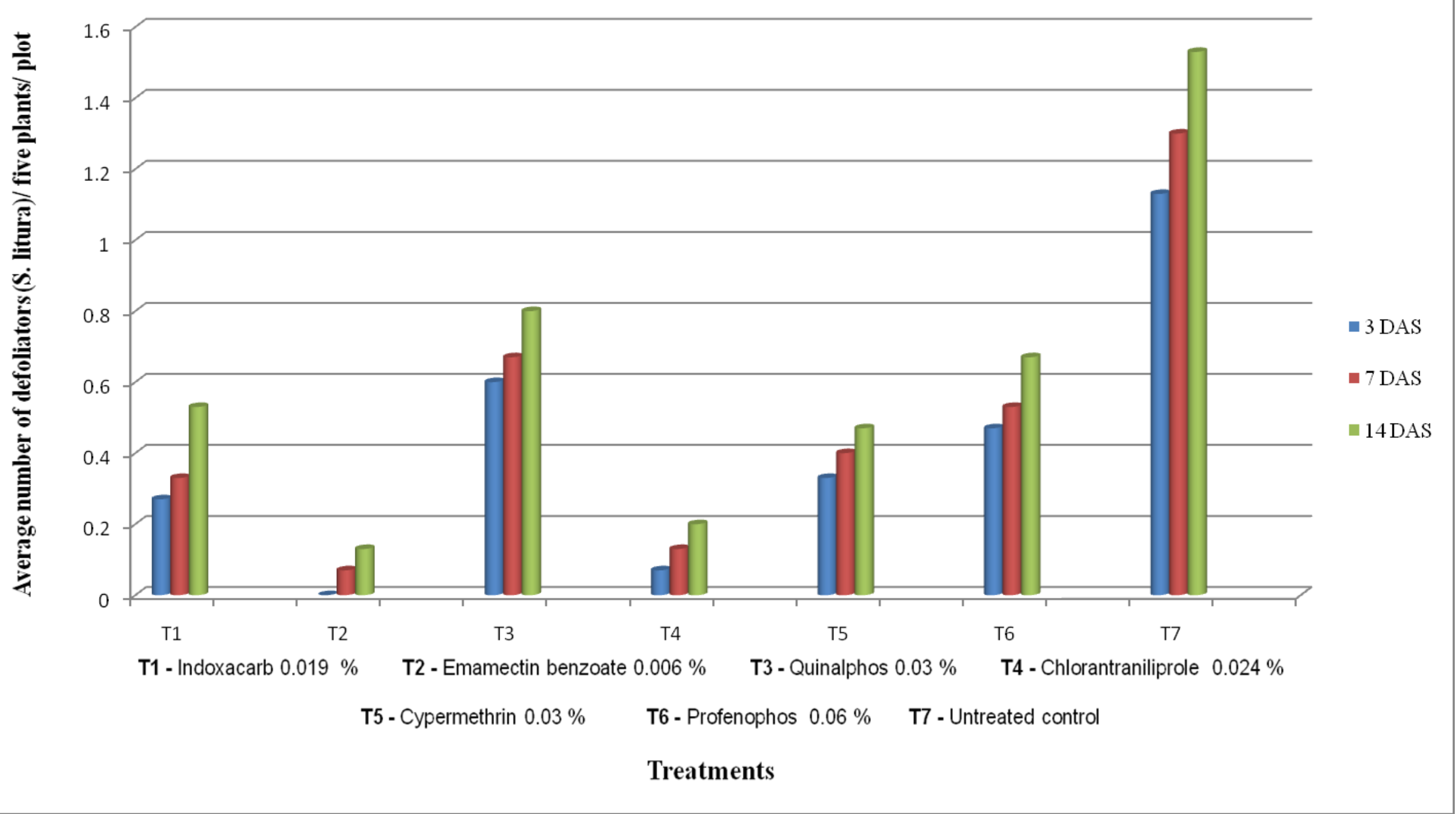


The next best treatment found in present study in the management of $S$. litura was chlorantraniliprole 18.5 SC @ 0.024 per cent. Gadhiya et al., (2013) ${ }^{[4]}$ and Naveen Kumar et al., (2015) ${ }^{[6]}$ found chlorantraniliprole effective against $S$. litura on groundnut. The effectiveness of chlorantraniliprole on soybean was also mentioned earlier by Bangale et al., (2019) ${ }^{[2]}$ and Patil et al., (2014) ${ }^{[10]}$. The next effective treatment found in present study in the management of $S$. litura was indoxacarb. Ravi et al., (2007) ${ }^{\text {[11] }}$ reported indoxacarb as an effective treatment for the management of $S$. litura on sunflower. Narayanamma et al., (2010) [7] found indoxacarb effective for the management of $S$. litura on castor. While indoxacarb as an effective treatment against $S$. litura was reported by Natikar et al., (2016) ${ }^{[8]}$ and Taggar et al., (2011) ${ }^{[14]}$ on soybean. Patra et al., (2016) ${ }^{[9]}$ found indoxacarb effective for the management of $S$. litura on cabbage. In the present study, profenophos and quinalphos were found least effective in management of $S$. litura. Sharma et al., (2017) ${ }^{[13]}$ found profenophos least effective in management of $S$. litura on soybean. Whereas, Bangale et al., (2019) [2] found quinalphos least effective in management of $S$. litura on soybean. Thus, the present finding of bio-efficacy experiment are in line with the findings of all these earlier workers.

The present study concluded that among the seven treatments, all the insecticidal treatments were effective than untreated control in reducing the Spodoptera litura population and emamectin benzoate 0.006 per cent was found most effective insecticide in controlling the Spodoptera litura population on sunflower.

\section{References}

1. Anonymous. Sunflower seed area, yield and production. Foreign Agricutural
Services/USDA, Office of Global Analysis 2019. https://apps.fas.usda.gov/psdonline/circ ulars/production.pdf.

2. Bangale SA, Parmar GM, Dhandge SR. Bio-efficacy of different insecticides against tobacco leaf eating caterpillar, Spodoptera litura (Fab.) infesting soybean under field condition. J. Entomol. Zool. Studies 2019; 8(1): 1014.

3. Basappa H. Integrated Pest Management in Sunflower in short course manual on advances in implementable pest management technology, Directorate of Oilseeds Research 1998, Hyderabad.

4. Gadhiya HA, Borad PK, Bhut JB. Effectiveness of synthetic insecticides against Helicoverpa armigera (Hubner) Hardwick and Spodoptera litura (Fabricius) infesting groundnut. Int. J. Life. Sci 2013; 9(1): 23-26.

5. Gomez KA, Gomez AA. Statistical procedures for agricultural research. John Wiley \& Sons 1984.

6. Kumar NN, Acharya MF, Srinivasulu DV, Sudarshan P. Bioefficacy of modern insecticides against Spodoptera litura Fabricius on groundnut. Int. J. Agric. Inn. Res 2015; 4(3): 573-577.

7. Narayanamma LV, Reddy AV, Singh TVK. Evaluation of newer insecticides for the management of defoliators and capsule borer in castor. Indian J. Pl. Protec 2010; 38(2): 144-146.

8. Natikar PK, Balikai RA, Jahagirdar S, Hosmath JA. Bio-efficacy of newer insecticide molecules against Spodoptera litura (Fab.) infesting soybean. Int. J. Agricult. Stat. Sci 2016; 12(1): 117-121.

9. Patra S, Das BC, Sarkar S, Samanta A. Efficacy of newer insecticides against major lepidopteran pests of cabbage. Res. On Crops 2016; 17(1): 144-150. 
10. Patil MU, Kulkarni AV, Gavkare Omkar. Evaluating the efficacy of novel molecules against soybean defoliators. Int. J. Life Sci 2014; 9(1): 577-580.

11. Ravi M, Sathiah N, Panneerselvam S. Management of sunflower head borers with biopesticides and newer insecticides. Madras Agric. J 2007; 94(1-6): 42-45.

12. Rohilla HR, Singh HV, Gupta DS, Kishan S. Pest complex other than diseases of sunflower, Helianthus annuus in Haryana. Indian J. Plant Prot 1981; 8: 177-182.

13. Sharma AK, Kumar A, Kumhar BL. Effective control measure of tobacco caterpillar (Spodoptera litura) on soybean through various insecticides. Chem. Sci. Rev. Lett 2017; 6(21): 533537.

14. Taggar GK, Cheema HK, Kooner BS. Bio-efficacy of certain insecticides against tobacco caterpillar, Spodoptera litura (Fabricius) infesting soybean in Punjab. Crop Research 2011; 42(1,2,3): 284-288.

15. Tatagar MH, Mohankumar HD, Shivaprasad M, Mesta RK. Bioefficacy of flubendiamide $20 \mathrm{WG}$ against chilli fruit borers, Helicoverpa armigera (Hub.) and Spodoptera litura (Fb.). Karnataka J. Agric. Sci 2009; 22(3): 579-581.

\section{How to cite this article:}

Jadhav, A.S., D.S. Mutkule, P.K. Waykule, B.A. Thakre and Dhormare, A.P. 2020. Bioefficacy of Different Insecticides against Defoliator (Spodoptera litura) on Sunflower. Int.J.Curr.Microbiol.App.Sci. 9(12): 1709-1718. doi: https://doi.org/10.20546/ijcmas.2020.912.203 